
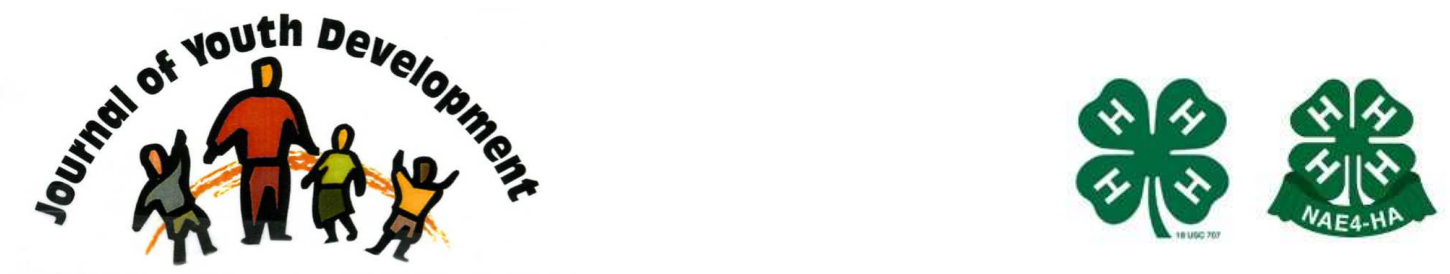

Bridging Research \& Practice

\title{
Digital Media Creates Youth Voices Heard
}

\author{
Jeff Sallee \\ 4-H Youth Development \\ Oklahoma State University \\ Stillwater, OK \\ Jeff.sallee@okstate.edu
}

Corbin Dewitt

4-H Youth Development

Oklahoma State University

Stillwater, OK

Corbin.Dewitt@okstate.edu 


\title{
JOURNAL OF YOUTH DEVELOPMENT \\ bridging research and practice

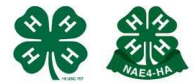

Volume 9, Number 2, Summer 2014

Article 140902PA002

\section{Digital Media Creates Youth Voices Heard}

\author{
Jeff Sallee and Corbin Dewitt \\ Oklahoma State University
}

\begin{abstract}
Oklahoma 4-H clubs and military service centers partnered with the Adobe Youth Voices (AYV) program to give youth opportunities to raise their voices through digital media. This program reached out to underrepresented youth and gave them the tools and technology to effectively express themselves. The intent of this project was for $4-\mathrm{H}$ members to create videos to educate, help and raise awareness in their communities of topics that were important to the youth. These experiences help youth gain knowledge towards helping others solve farm, home, and community problems. Participating youth selected issues that were important to them and created a short video, educating others and sharing their convictions on the topics of horse therapy, citizenship, bullying, and distracted driving.
\end{abstract}

\section{Introduction}

Oklahoma 4-H clubs and military service centers partnered with the Adobe Youth Voices (AYV, 2013) program to give youth opportunities to raise their voices through digital media. This program reached out to underrepresented youth and gave them the tools and technology to effectively express themselves. Participating youth selected issues that were important to them and created a short video, educating others and sharing their convictions on the topics of horse therapy, citizenship, bullying, and distracted driving. The service-learning model contributed to much of the success of these digital media projects.

"Service learning provides the critical missing link for many students, an opportunity to apply academic learning to real human needs and to make the knowledge gained usable in one's thinking beyond the situation in which the learning occurred" (Hedin, 1989). Effective service learning programs include working with program participants and community members, educating everyone involved on the selected topic, and learning outside the classroom. Service learning is a method of learning and teaching with the greatest intent to help, educate, and support other people; it is an activity done for the greater good.

Throughout the service-learning process young people should have an active voice in planning and implementing the project (Bruce, Webster, \& Hoover, 2006). The 4-H youth who 
participated in this service project created videos for the greater good. Their intent was to use their video to educate, and help raise awareness in others. That is what makes this project and type of learning so remarkable. Service learning projects help youth develop the tools and experience to be effective leaders in their community (Hentschel, 2010) by allowing youth to develop critical thinking skills, engage in problem solving, and explore potential career options.

These digital media projects were the result of an effective partnership between the Oklahoma 4-H Youth Development program (4-H), Adobe Youth Voices program (AYV), and the Child and Youth Service Centers (CYS) located on Ft. Sill and Tinker Air Force Base. Programs such as these take a high level of cooperation, commitment, dedication, and tenacity to complete. Other 4-H clubs and CYS programs participated in this project but were unable to complete their digital media piece.

The Oklahoma 4-H program is a branch of the Cooperative Extension Service (Extension). When we think of 4-H, Extension, and young people, we are inclined to think of the motto, "learning by doing." This motto has lead youth to become active and productive through projects and experiences (Webster, 2006). Extension is in a prime position to assist the learning experiences of youth through hands-on learning, just as the motto "learning by doing" reflects (Bourdeau, 2004; Hairston, 2004). The objective of Extension 4-H programs is to plan, execute, and evaluate learning experiences. These experiences help people gain knowledge or skills towards helping them solve farm, home, and or community problems. Cooperative Extension Services were established by the Smith - Lever Act in 1914. This Act created the Cooperative Extension Services through the land grant universities. Extension has three levels of organization, federal, state, and county (Cooperative Extension Services, 2013).

The Adobe Youth Voice (AYV) program aims to empower youth in underserved communities around the globe with real-world experiences and $21^{\text {st }}$ century tools to communicate their ideas, exhibit their potential, and take action in their communities (Adobe youth voices, 2013). With a focus on empowering youth, Oklahoma 4-H and AYV support young people in and out of school, and encourage the use of cutting-edge multimedia tools to communicate, share their ideas, demonstrate their potential, and take action where they live (Adobe youth voices, 2013). The youth involved in this project tell their story through the videos they created. The subjects of their media were selected by the participating youth based on an issue that directly affected them. Examples of the subjects of the videos include the importance of studying, anti-bullying and the consequences of distracted driving. The 4-H youth created videos with the intent to show them to the public and other youth with the goal of raising awareness about the issues they were addressing.

Often times it is difficult for educators to measure the degree to which service learning projects are beneficial to youth due to the fact that there are no concrete means of measuring the effect a service-learning project has on participants. A Pennsylvania State University research team collected information to develop a template for educators to use when conducting service learning activities with youth (Bruce, Webster, \& Hoover, 2006). The team conducted interviews with a group of young people who were involved in service learning activities at the time. The comments provided by the young people who were interviewed supported the ideas that young adults have the responsibility to be leaders; they step forward and volunteer; and they express the voices that drive service related activities (Bruce, Webster, \& Hoover, 2006). The conclusions based upon the study were that young people should be active participants in their service learning projects' programs. Their ideas and voices should be included and utilized in the decision-making process. Adult volunteers should be trained before working with the youth 
as a means of insuring that the importance of youth voice and leadership is emphasized (Bruce, Webster, \& Hoover, 2006). Finally, service learning as a method of teaching and learning should continue to be incorporated into all levels and types of programming within the Cooperative Extension Service (Bruce, Webster, \& Hoover, 2006).

\section{Program Overview}

The 4-H AYV project had four participating locations that completed the project. These locations included the two Oklahoma Military Child and Youth Centers and two 4-H Clubs; Fort Sill, Tinker Air force Base, Pittsburg County 4-H, and Garfield County 4-H. The project was designed through service learning to give youth a voice in creating digital media. The youth decided what types of media they wanted to use and the delivery mode. The participants also were given the opportunity to showcase their digital media through community/public presentations.

\section{Pittsburg County 4-H}

Pittsburg County 4-H youth learned a great deal about the process of film making. More importantly, they learned about communication, time management, and decision-making. The youth from Pittsburg 4-H created several videos about the Therapeutic Equestrian Association of McAlester (TEAM). Their videos presented the history of the association, the services it provides, and a testimony from a father whose child has benefitted from the association.

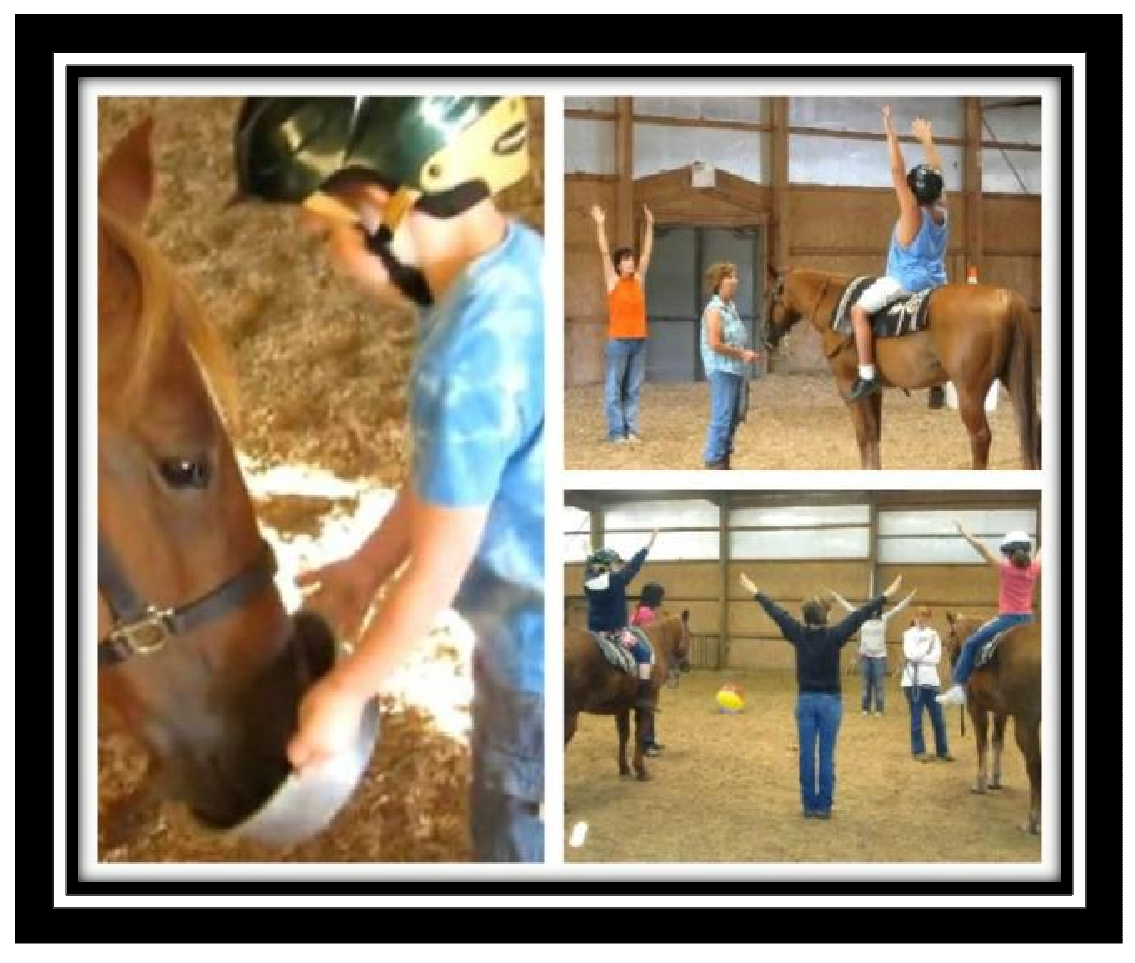

The Pittsburg County 4-H TEAM video was showcased at their county 4-H program's annual appreciation banquet. The Pittsburg County 4-H TEAM demonstrated service learning perfectly through their project. The youth have researched projects and educated other youth and adults with the intent to help and to exemplify the 4-H motto of "Making the Best Better." Showcasing the video resulted in more youth volunteering with the Therapeutic Equestrian Association of 
McAlester (TEAM). Following this project, Pittsburg 4-H members discovered many opportunities to collaborate with community groups using digital media. With so many new opportunities to create videos, the youth have learned to prioritize and schedule projects, which is another great life skill. Pittsburg 4-H uploaded several of their videos to YouTube, Facebook and used the $\mathrm{mp} 2$ version to email their videos to other counties in Oklahoma. They have also received requests from around the nation to use their TEAM video as an example for other 4-H programs. The ultimate purpose of their video was to raise awareness of the TEAM program and help raise funding for the construction of a new facility. These youth now see the real impact of using videos to speak out and express their voice. Pittsburg 4-H youth have overcome their fears and learned that what they have to say is important.

\section{Fort Sill}

The Fort Sill Youth Center recognized interested youth and worked with them in small group settings to learn about the AYV software, brainstorm project ideas, create a project, and complete the evaluation process. Fort Sill's video was titled "How I show I am a good citizen." Their video highlighted youth sharing with one another, being kind to others, and having responsibility. Through creating their video, Fort Sill youth wanted to show other youth that "Character Counts." Having a sense of character is a crucial part of daily life for military youth. This program gave the Fort Sill youth an opportunity to express themselves in a positive way towards others. They were able to show their video at the youth center and showcase their voice to family, friends and other youth in the Fort Sill Youth Center.

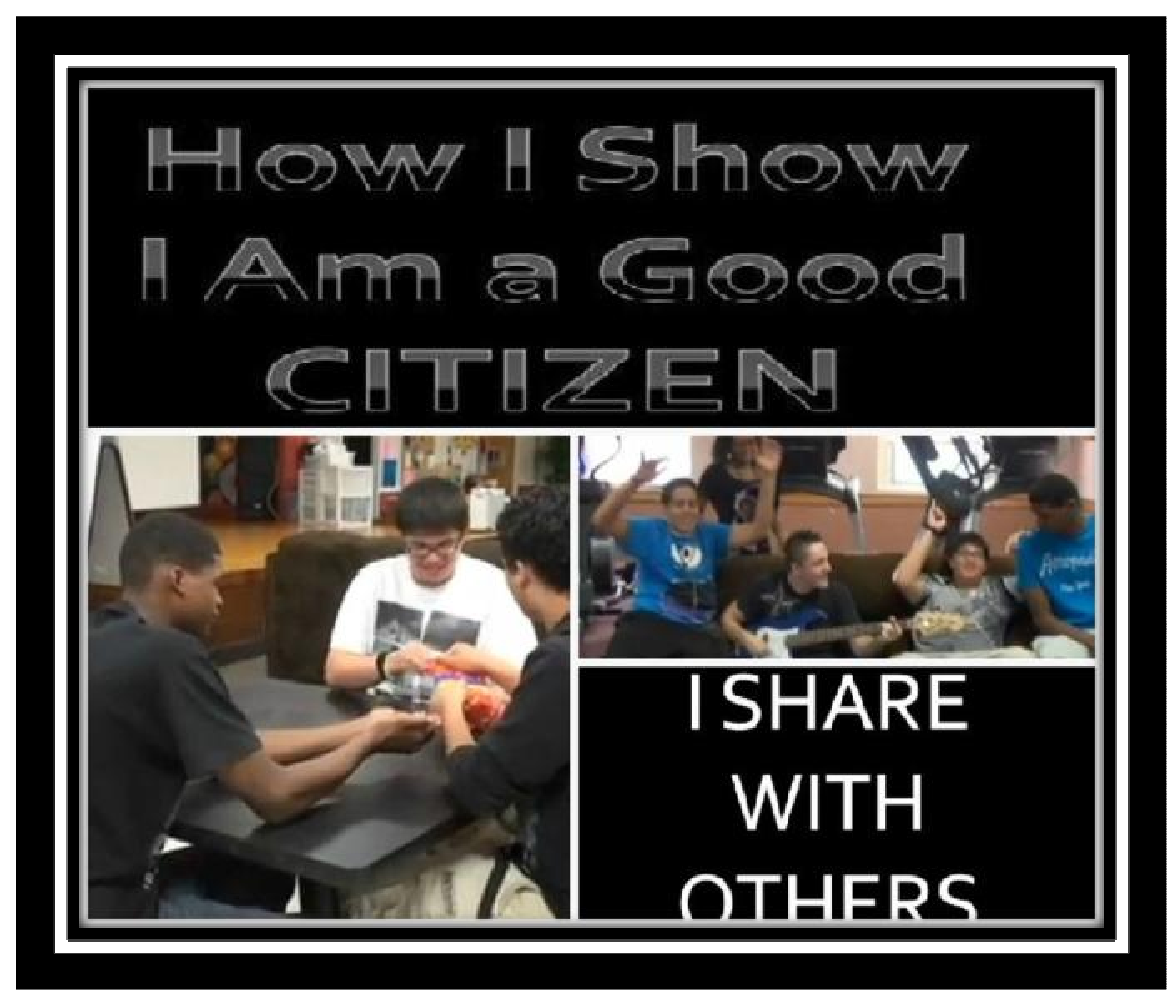




\section{Tinker Air Force Base}

Tinker AFB Youth Center was very proactive in its attempt to gain the most members they could for this project. They used flyers, placed information on marquees, and personally invited youth that they knew would have an interest in the program. The Tinker youth promoted the idea that there were more positions for the youth to participate in than just being on camera. They would need help filming the video and editing the final project. The participating youth were asked about issues they saw at school or at their youth center that go unnoticed. They decided to create a video that would open other youth's eyes to the negative effects of bullying. Tinker youth were very creative. Videoing an everyday task, they would then hold up a sign with a short statement of encouragement to put a stop to bullying. This project offered the youth of Tinker the chance to learn and operate video equipment, use Adobe software, and understand the time and hard work it takes to create a final media piece. Tinker youth enjoyed developing their video and using it to express their voice with other youth by showing them their "AntiBullying" video.

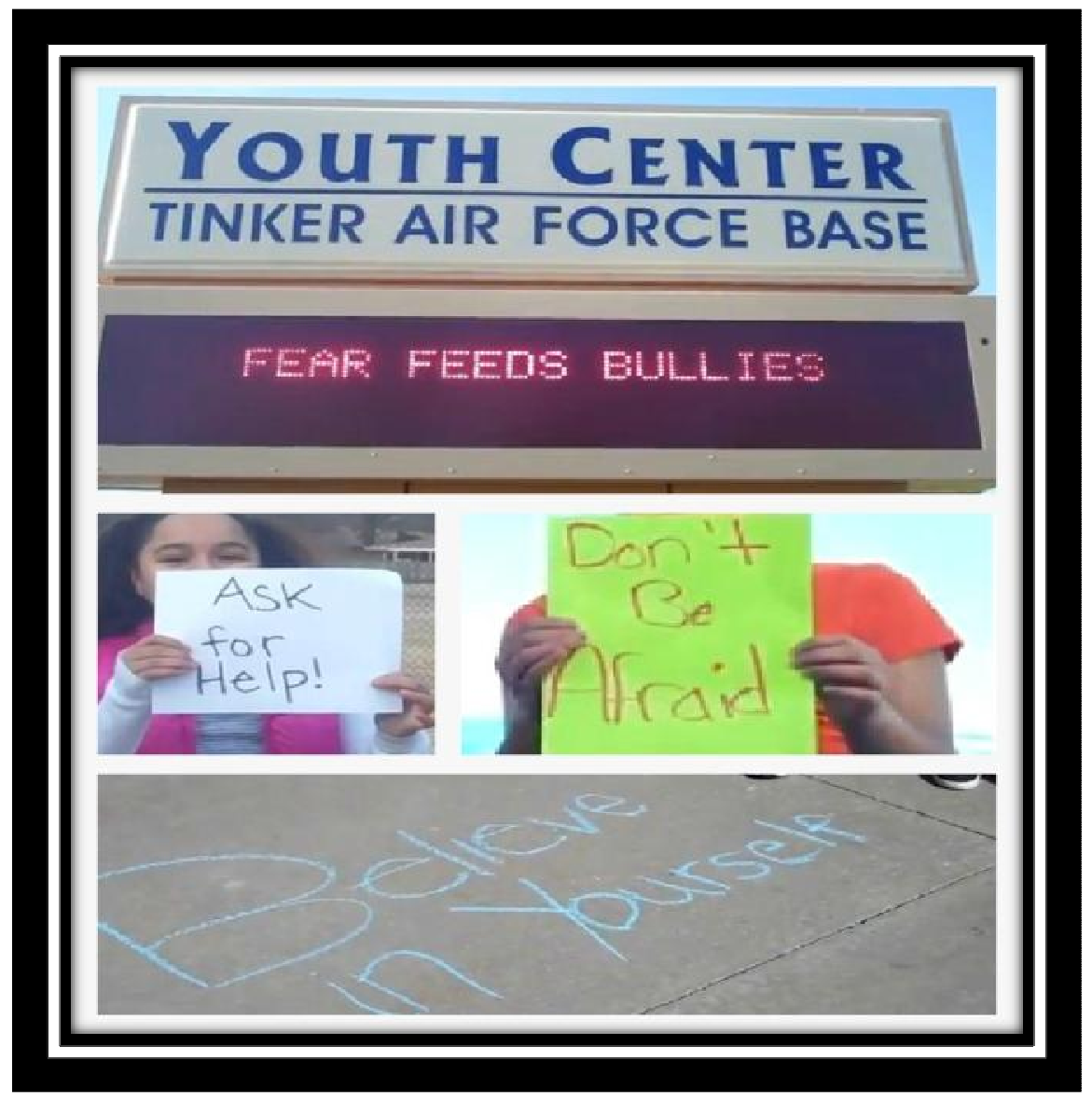

\section{Garfield County 4-H}

Garfield County 4-H club created a video about "Distracted Driving." Youth working on this project almost lost a friend in a car accident that involved a driver distracted by texting. The teens working on this video really enjoyed researching statistics on car accidents related to drivers being distracted. They utilized their annual 4-H camp to practice creating videos by making short films before creating their "Distracted Driving" video. The youth continued to 
practice until they become more aware of background noises and landscapes while refining their videography techniques. After finishing this project, these youth now realize the best way to end distracted driving is to educate everyone about the danger it poses. Garfield County 4-H members showcased their video all day at their Northwest Oklahoma 4-H District Mall Day.

Studies show eating while driving causes $80 \%$ of accidents

Applying makeup or shaving while driving increases your chance of crashing by about three times.
For each friend you add to your car, your crash risk doubles. With two or more passengers, the fatal crash risk is five times higher than driving alone.
Reaching for an object within the car or adjusting the radio increases the risk of a crash or near-crash by nine times

The youth who created these videos gained more than a fun experience. They gained life skills, learned to lead, used critical thinking, took part in their communities, and developed personally as individuals.

\section{Conclusion}

Service learning opportunities need to be provided for our youth. These experiences can positively influence their lives. The partnership of 4-H and Adobe Youth gave youth the opportunity to explore. It gave them the opportunity to work together and find a solution to a problem that would better serve their home community. Youth who participated in these service learning projects had a positive effect on others. They became involved in their communities, solved real world issues, and, thanks to their digital media projects, their voice was heard.

\section{References}

Adobe youth voices. (2013). Retrieved from http://www.adobe.com/in/campaigns/corporateresponsibility/youth-voices.html.

Bourdeau, V.D. (2004). 4-H experiential education--a model for 4-H science as inquiry. Journal of Extension , 42(5), Retrieved from: http://www.joe.org/joe/2004october/tt3.php. 
Bruce, J.A., Webster, N.S., \& Hoover, T.S. (2006). Developing youth voice in service learning projects. Journal of Extension, 44(4), Retrieved from:

http://www.joe.org/joe/2006august/tt1.php.

Cooperative Extension Services. (2013). Retrieved from:

http://encyclopedia2. thefreedictionary.com/Cooperative+Extension+Services.

Hairston, J.E. (2004). Identifying what 4-H'ers learn from community service learning projects. Journal of Extension, 42(1), Retrieved from: http://www.joe.org/joe/2004february/rb4.php.

Hedin, D.P. (1989). Proceedings of the academy of political science. The Academy of Political Science, 372), 201-213. Retrieved from: http://www.jstor.org/stable/1173962.

Hentschel, M. (2010). The benefits of service-learning to students. Retrieved from: http://tilt.colostate.edu/sl/students/benefits.cfm.

Webster, N. (2006). Incorporating service learning and extension in inner city middle schools: A model for future programming. Journal of Extension, 44(1), Retrieved from:

http://www.joe.org/joe/2006february/iw1.php

(C) Copyright of Journal of Youth Development Bridging Research and Practice. Content may not be copied or emailed to multiple sites or posted to a listserv without copyright holder's express written permission. Contact Editor at: patricia.dawson@oregonstate.edu for details. However, users may print, download or email articles for individual use.

ISSN 2325-4009 (Print); ISSN 2325-4017 (Online) 